\title{
DIA DO PESQUISADOR CIENTÍFICO BRASILEIRO
}

\author{
Alcino Lázaro da Silva \\ Professor de Cirurgia e Emérito da UFMG.
}

"Alea jact est" (A sorte está lançada). A decisão, com base numa necessidade intelectual, foi a de criar uma Revista para a Comunidade Experimental.

"Ad astra per aspera ou Ad augusta per augusta" (Por caminhos ásperos se chega aos astros).

Foi esse o início da Acta Cirúrgica Brasileira que tive a honra de receber, acompanhar e arquivar o seu primeiro número, elaborado a partir de 17 de setembro de 1987.

Prof. Saul, sabiamente, saudavelmente e com sapiência, congregou os seus mais íntimos colaboradores e depois os novos agregados na idéia sadia de comunicação em pesquisa.

Agregar é qualidade de quem possui a vontade de reunir para desdobrar-se. "Facile est imperium in bonis" (E' fácil comandar homens valentes).

Todo o começo é cego, imprevisível e incerto. Começar é abrir as portas do desconhecido para se tornar uma realidade, ainda que árdua e duramente conquistada. "Vulnera qui passus fuit, est bonus ille chirurgus" (Não há melhor cirurgião, que o bem acutilado).

Começou. E daí ? Há que mantê-la. A manutenção custa muito quando se trata de atividade sem lucros e voltada para o doce e sofrido mister de preparar seguidores. "In capite orphani discit chirurgus" (Na cabeça do órfão aprende o cirurgião).

Manter é tolerar. Tolerar é árduo também porque exige obstinação e perseverança. Nesta, se inclui o ideal de que se investe, para a comunidade científica obter um retorno afetivo, cultural, espiritual, psíquico e até material em casos excepcionais. "Obsequium amicos, veritas odium parit" (O favor faz amigos e a verdade inimigos).

A Acta passou pela aspereza do início, pela agregação difícil e pela difícil manutenção da idéia (ou do sonho). Navegou na perseverança, balançou-se na preservação e hoje regozija-se da continuidade que possui, usufruindo o privilégio de uma indexação completa.

Ela foi produto de quê ? De numerosos fatores, entre identificados ou não e entre importantes ou secundários. Houve o professor (es); houve a vontade de organizar cursos regulares de pós-graduação, a exemplo de dezenas de pares brasileiros de mesma qualidade e objetivos; os professores se dedicando à causa nobre de formarem homens universitários; os alunos se sacrificando em favor de sua qualificação e crescimento e as universidades a abrirem espaços. No mais nobre entre tudo, está o pesquisador. "Amor ordinem nescit" (O amor não conhece a ordem).

Estamos vivendo, também, a cultura do "Dia". Todos os que colaboram com a manutenção e o equilíbrio da humanidade recebem uma homenagem por meio da comemoração do seu "Dia".

Se formos buscar no elenco das profissões julgo, até prova em contrário, que não havia o Dia do Pesquisador.

O que nos cabe, então, como conviventes com esta classe que faz o mundo evoluir no crescimento técnico ou humanístico ? É obvio. Criar o "Dia do Pesquisador", para celebrá-lo.
A iniciativa foi tomada pelo professor Saul. Solicitou e motivou o deputado Adolfo Lobbe Neto a convencer os seus pares e o fez com tanta eficácia que se criou o "Dia do Pesquisador" no estado de São Paulo. Apresentou o Projeto de Lei № 1.869/2003, instituindo o Dia do Pesquisador Brasileiro a ser comemorado no dia 22 de agosto. Além deste, ele relatou outro, 7.577/2006, com os mesmos objetivos a ser comemorado no dia 8 de julho, no Senado Federal. Aprovado, foi para o Deputado Eduardo Cunha que era o presidente da Comissão de Constituição e Justiça e de Cidadania do Senado Federal. "Amor vincit omnia" (O amor tudo vence).

A pergunta óbvia é: por que o dia 17/09/1987? A resposta, sobre a legitimidade da data é que no mesmo dia comemora-se o nascimento da Sociedade Brasileira para o Desenvolvimento da Pesquisa em Cirurgia (SOBRADPEC).

A proposta me foi repassada. Procurei o caminho da governabilidade e por meio do deputado - médico Hely Tarquínio fez-se a proposta, aprovada pela Assembléia Legislativa de Minas Gerais e confirmada pela assinatura do governador Aécio Neves, registrada no Diário Oficial em 30/12/2008 (Lei $N^{\circ} 1.789$ ), criando-se o Dia Estadual do Pesquisador Científico em Minas Gerais, no dia 15 de fevereiro . Nesse mesmo dia a humanidade celebra o nascimento de Galilelo Galillei, um dos marcos da pesquisa mundial. (Lei $\mathrm{N}^{\mathrm{o}} 1.789$ ).

Não satisfeito, subi um pouco mais e o Senador Eduardo Brandão Azeredo, criou a lei 11.807 de 13/11/2008, sancionada pelo Vice Presidente da República, o mineiro José de Alencar, em exercício no cargo da Presidência. Ficou criado o Dia Nacional do Pesquisador em 8 de julho, homenageando a fundação da Sociedade Brasileira para o Progresso da Ciência (SBPC).

"In ardua virtus" (O valor consiste em se opor às dificuldades).

Como resolver essa aparente diversificação ao homenagearmos o pesquisador brasileiro ? Dia 17 de setembro em São Paulo; dia 15 de fevereiro em Minas Gerais e no Brasil, dia 8 de julho.

O que interessava era criar a data para comemorar. Cada um julgou oportuno escolher o marco motivado pela importância do patrono. O desejo se concretizou e há, agora, o que discutir e caminhar-se para um consenso. "Alii sementem faciunt, alii metent" (Uns plantam, outros colhem). O que vale, então, é termos resolvido um fato inexistente, até agora. Há o reconhecimento, há o "Dia" para a comemoração e falta -nos, pois, procurar equilibrar as opiniões dos pesquisadores e buscar a unidade de pensamento para que as sementes só gerem progresso, concórdia e paz. "Sit salvus sator, salva sint sata" (Bendito seja o semeador, benditas sejam as sementeiras).

Cabe agora ao Legislador ou às Sociedades de Pesquisa, se organizarem, se entenderem e, em conjunto, formularem uma proposta final, definitiva e nacional. As datas citadas ficam na história pois a partir delas é que se nacionalizou o Dia do Pesquisador Brasileiro. 